\title{
4th year medical student elective in multidisciplinary thoracic oncology
}

\author{
LE Quint", RM Reddy \\ From International Cancer Imaging Society Meeting and 15th Annual Teaching Course (ICIS 2015) \\ London, UK. 5-7 October 2015
}

\section{Learning objective}

The objectives of this poster are to describe the methodology and curriculum content employed by a senior medical student elective entitled "Multidisciplinary Thoracic Oncology." This elective provides students with experience in a focused area of oncologic practice and is valuable to those pursuing careers in a variety of related fields.

\section{Content description}

This month-long elective employs a flipped classroom approach with didactic teaching materials that are delivered on an interactive online platform. Materials include recorded videolectures with pre-lecture, post-lecture and embedded multiple choice questions (MCQs); case studies with a sequential, question and answer learning approach and embedded MCQs; a pre-course quiz and a post-course exam. These didactic materials are viewed by students at their own time and pace, typically during off hours. During daytime hours, the students rotate through relevant clinics, seeing patients and reviewing their cases with attending faculty, and occasionally assisting in surgical/interventional procedures. The areas covered include Medical Oncology, Pathology, Pulmonology, Radiation Oncology, Radiology and Thoracic Surgery, focusing on patients with lung, esophageal and other thoracic neoplasms. Each student presents one or more patients at the weekly Thoracic Tumour Board meeting. The capstone project is a written case study or an oral presentation based on a relevant topic. Comments from students who took this elective during the past year indicated enjoyment of: "full engagement in the learning process and the patient care team" and "obtaining a wellrounded, multidisciplinary understanding of the presentation and treatment of these patients."

\footnotetext{
* Correspondence: lequint@umich.edu

University of Michigan, 500 S State St, Ann Arbor, MI, USA
}

Published: 2 October 2015

doi:10.1186/1470-7330-15-S1-P23

Cite this article as: Quint and Reddy: 4th year medical student elective in multidisciplinary thoracic oncology. Cancer Imaging 2015 15(Suppl 1):P23.
Submit your next manuscript to BioMed Central and take full advantage of:

- Convenient online submission

- Thorough peer review

- No space constraints or color figure charges

- Immediate publication on acceptance

- Inclusion in PubMed, CAS, Scopus and Google Scholar

- Research which is freely available for redistribution
() Biomed Central

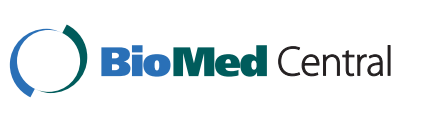

